\title{
Soil moisture redistribution and its effect on inter-annual active layer temperature and thickness variations in a dry loess terrace in Adventdalen, Svalbard
}

\author{
Carina Schuh $^{1}$, Andrew Frampton ${ }^{1,2}$, and Hanne Hvidtfeldt Christiansen ${ }^{3}$ \\ ${ }^{1}$ Department of Physical Geography, Stockholm University, Stockholm, Sweden \\ ${ }^{2}$ Bolin Centre for Climate Change, Stockholm University, Stockholm, Sweden \\ ${ }^{3}$ Department of Arctic Geology, The University Centre in Svalbard, Longyearbyen, Norway
}

Correspondence to: Andrew Frampton (andrew.frampton@ natgeo.su.se)

Received: 11 July 2016 - Discussion started: 10 August 2016

Revised: 5 January 2017 - Accepted: 18 January 2017 - Published: 28 February 2017

\begin{abstract}
High-resolution field data for the period 20002014 consisting of active layer and permafrost temperature, active layer soil moisture, and thaw depth progression from the UNISCALM research site in Adventdalen, Svalbard, is combined with a physically based coupled cryotic and hydrogeological model to investigate active layer dynamics. The site is a loess-covered river terrace characterized by dry conditions with little to no summer infiltration and an unsaturated active layer. A range of soil moisture characteristic curves consistent with loess sediments is considered and their effects on ice and moisture redistribution, heat flux, energy storage through latent heat transfer, and active layer thickness is investigated and quantified based on hydro-climatic site conditions. Results show that soil moisture retention characteristics exhibit notable control on ice distribution and circulation within the active layer through cryosuction and are subject to seasonal variability and sitespecific surface temperature variations. The retention characteristics also impact unfrozen water and ice content in the permafrost. Although these effects lead to differences in thaw progression rates, the resulting inter-annual variability in active layer thickness is not large. Field data analysis reveals that variations in summer degree days do not notably affect the active layer thaw depths; instead, a cumulative winter degree day index is found to more significantly control interannual active layer thickness variation at this site. A tendency of increasing winter temperatures is found to cause a general warming of the subsurface down to $10 \mathrm{~m}$ depth $(0.05$ to $0.26^{\circ} \mathrm{C} \mathrm{yr}^{-1}$, observed and modelled) including an increas-
\end{abstract}

ing active layer thickness $\left(0.8 \mathrm{~cm} \mathrm{yr}^{-1}\right.$, observed and 0.3 to $0.8 \mathrm{~cm} \mathrm{yr}^{-1}$, modelled) during the 14-year study period.

\section{Introduction}

Permafrost environments have been identified as key components of the global climate system given their influence on energy exchanges, hydrological processes, carbon budgets and natural hazards (Riseborough et al., 2008; Schuur et al., 2015). Over the last 30 years, air temperatures in polar regions have increased by $0.6^{\circ} \mathrm{C}$ per decade, which is twice the global average (IPCC, 2013). On Svalbard, long-term records indicate an increase in mean annual air temperature of $0.2^{\circ} \mathrm{C}$ per decade since the beginning of the 20th century (Humlum et al., 2011), and permafrost warming has been detected to a depth of $60 \mathrm{~m}$ based on borehole measurements (Isaksen et al., 2007). The relationship between climate and permafrost temperatures is, however, highly complex. Changes in active layer thickness can be buffered from effects of changing air temperatures by vegetation, snow cover, and permafrost ice content and its thermal state, as well as by variable heat and water flows occurring in the active layer. The active layer is important in cold regions, where thermal and hydrological processes determine local phenomena such as erosion, and hydrological and ecosystem changes (Karlsson et al., 2012; Lyon et al., 2009; Walvoord and Kurylyk, 2016; Walvoord and Striegl, 2007), and has implications for solute and carbon transport (Frampton and Destouni, 2015; Giesler et al., 2014; 
Jantze et al., 2013) and the global carbon-climate feedback (Tarnocai et al., 2009).

Both soil moisture and the thickness of the active layer have been identified as essential climate variables (GCOS, 2015). Soil moisture is an important variable for energy exchange and governs the processes occurring at the landatmosphere interface by partitioning incoming solar radiation into fluxes of latent and sensible heat. Also, soil moisture controls subsurface physical properties such as thermal conductivity and heat capacity, so that the movement and distribution of moisture within the subsurface is essential for understanding the water and heat balance of the ground, particularly in cold climates (Wu et al., 2015). Still, most studies on permafrost thaw projections mainly investigate the structural uncertainty in climate models, whereas the parametric uncertainty in soil properties is barely accounted for (Harp et al., 2016). Active layer thickness, in contrast, is one of the most distinct indicators of permafrost change, which is why the response of the active layer to climatic variations has been studied using climatic and ground thermal monitoring in several Arctic regions (Frauenfeld, 2004; Lafrenière et al., 2013; Osterkamp, 2007). On Svalbard, Roth and Boike (2001) quantified the soil thermal properties and conductive heat fluxes for an experimental site near Ny-Ålesund based on subsurface temperature data and soil moisture measurements. Akerman (2005) monitored active layer depths over several decades in the Kapp Linné area with regard to periglacial slope processes, and found active layer deepening to correlate well with increased air temperature. Isaksen et al. (2007) reported rising permafrost temperatures with accompanying increases in active layer depths, when evaluating thermal monitoring data for the $100 \mathrm{~m}$ deep Janssonhaugen borehole penetrating a bedrock hill in inner Adventdalen over a period of 6 years. For the period 2000-2007, Christiansen and Humlum (2008) used a combined consideration of thermal monitoring data and Circumpolar Active Layer Monitoring (CALM) measurements to derive key controlling factors of active layer development, which turned out to be mainly air temperature and solar radiation, at the UNISCALM study site in Adventdalen, central Svalbard.

The physics of thermal conduction and latent heat transfer has been the basis of several studies on permafrost dynamics and active layer processes (Hinzman et al., 1998; Kane et al., 1991; Shiklomanov and Nelson, 1999; Smith and Riseborough, 2010; Zhang et al., 2008). Studies have also proceeded beyond analysis of monitoring data to explore active layer dynamics; Westermann et al. (2010) used ground penetrating radar to identify the link between soil moisture content and thaw depths at Ny-Ålesund, and Watanabe et al. (2012) applied electrical resistivity tomography to identify the seasonal variation in thaw depth in an alluvial fan in Adventdalen. Several recent advances in permafrost and active layer model development have been made, in particular in the field of coupled thermal-hydrogeological models of partially frozen ground (Bense et al., 2009; Karra et al.,
2014; McKenzie et al., 2007; Painter, 2011). This has enabled studies on effects of permafrost degradation on changes in groundwater flows (Kurylyk et al., 2016; Scheidegger and Bense, 2014; Sjöberg et al., 2016), in particular showing expected increase in base flow and decrease in seasonal variability in discharge under warming (Frampton et al., 2013, 2011; Walvoord et al., 2012) and increased pathway lengths and delays in solute mass transport and breakthrough due to non-linear active layer thickness increase (Frampton and Destouni, 2015).

In this study, a comprehensive long-term monitoring data set collected between 2000 and 2014 at the UNISCALM research site in Adventdalen, Svalbard, which includes ground temperature, soil moisture, and active layer thaw depth progression, is applied to a physically based numerical model for partially frozen ground to investigate subsurface processes controlling active layer dynamics. This site is characterized by little precipitation and dry unsaturated conditions in the active layer. In this particular environment, soil water retention is a critical but also highly uncertain parameter, which we investigate based on a range of characteristic retention curves commonly ascribed to the dominant sediment type (silt loam) of the location. The aim is to study how soil moisture retention properties affect moisture and ice redistribution as well as subsurface temperature and active layer thickness variations in the partially saturated active layer under multiple freeze-thaw cycles. Using a scenario analysis approach, different soil moisture retention properties are expressed through careful selection of relevant parameter values derived from field information, and simulation results are then placed in the context of the UNISCALM site as well as other relevant permafrost environments.

\section{Site description}

Adventdalen, located in the central part of Svalbard, is a typical U-shaped valley that dissects a landscape with peaks, ridges, and plateaus. The valley is partially filled by periglacial sediments primarily in the form of colluvial, alluvial, and aeolian deposits. During about four months of summer, mainly between June and September, the braided river system of Adventelva discharges into Adventfjorden (Killingtveit et al., 2003). The tributary streams draining to Adventelva have built up large alluvial fans on both sides of the valley, and several river terraces have been described that confine the braided channel system of Adventelva, and can extend up to several meters above river elevation (Bryant, 1982).

The UNISCALM site $\left(78^{\circ} 12^{\prime} \mathrm{N}, 15^{\circ} 45^{\prime} \mathrm{E}\right)$ is located on a terrace on the southern side of Adventelva at an elevation of $10 \mathrm{~m}$ a.s.l. (Fig. 1). The upper $1.3 \mathrm{~m}$ of sediment has been described as horizontally layered loess, i.e. silt-dominated aeolian sediment (Christiansen and Humlum, 2008). Information from adjacent boreholes and several study sites in 


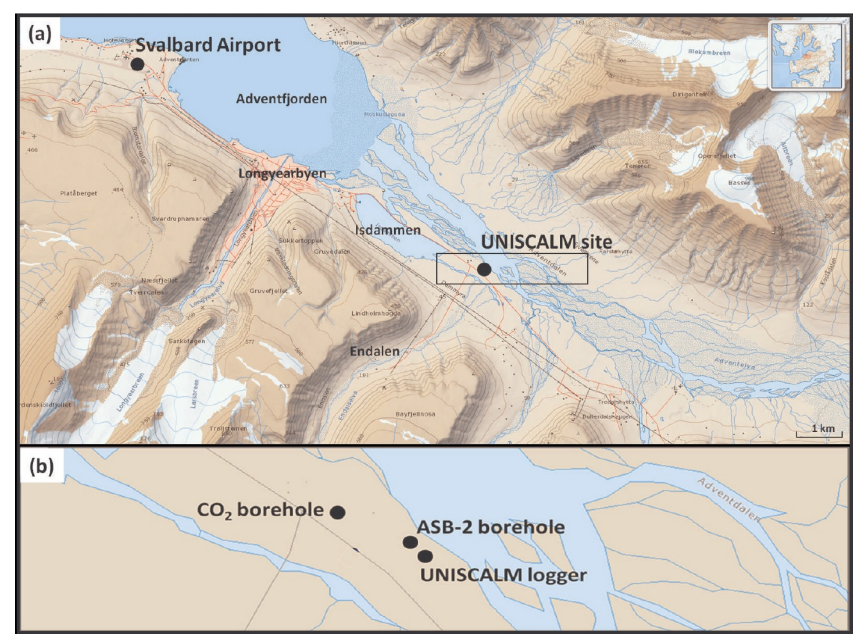

Figure 1. Lower Adventdalen in central Spitsbergen, Svalbard, showing the location of the UNISCALM site. The meteorological station is located at Svalbard Airport (data: Norwegian Polar Institute).

the downstream part of the valley supports this classification, and provides evidence of fine-grained, silt-dominated largely deltaic sediment with interbedded clay and sand down to a depth of $60 \mathrm{~m}$ (Gilbert, 2014). The site is sparsely covered by typical arctic tundra vegetation consisting of mosses and low vascular plants like Salix herbacea and sedges (Bryant, 1982).

Cryostratigraphic information obtained from cores shows ice saturation in the top permafrost and considerable excess ice (up to $50 \%$ ) at around $2.0-4.5 \mathrm{~m}$ depth in several boreholes in lower Adventdalen, with total carbon content estimated and measured to be only about $1-5 \%(\mathrm{H}$. H. Christiansen, personal communication, 2015), so that no considerable thermal insulation effects through soil carbon are to be expected (Koven et al., 2009). Despite its location at the outlet of the valley Endalen, the UNISCALM site is not influenced by surface runoff or lateral subsurface flows, since it is cut-off from the upper part of the alluvial fan filling lower Endalen by a road construction. Endalselva drains the valley and discharges directly into the local water reservoir Isdammen (Fig. 1), leaving the UNISCALM site unaffected from increased snow and glacial melt water runoff during spring and summer. Only snow, which covers the site at the end of winter and which does not sublimate, may infiltrate the ground during snow melt.

Permafrost is continuous in Svalbard and can extend to $500 \mathrm{~m}$ depth in the mountains, whereas in the valley bottoms, such as in Adventdalen, the permafrost thickness is estimated to be about $100 \mathrm{~m}$ (Humlum, 2005). Ground temperature records from a $10 \mathrm{~m}$ deep borehole (ASB-2) adjacent to the UNISCALM site show that between 2009 and 2013, the mean monthly ground surface temperature ranged from $-13.1^{\circ} \mathrm{C}$ in March to $+9.8^{\circ} \mathrm{C}$ in July (Juliussen et al.,
2010); also the depth of zero annual amplitude was observed at $-9.85 \mathrm{~m}$ depth with a mean temperature of $-5.5^{\circ} \mathrm{C}$, and with an average annual increase of $0.05^{\circ} \mathrm{C} \mathrm{yr}^{-1}$.

Svalbard airport is the nearest official meteorological station located about $8 \mathrm{~km}$ northwest from the UNISCALM site (Fig. 1) and is closer to the sea and at a slightly higher elevation ( $28 \mathrm{~m}$ a.s.l.). Based on records from Svalbard airport (data from Norwegian Meteorological Institute, 2014) annual mean air temperature during the study period was $-3.6^{\circ} \mathrm{C}$ and mean annual precipitation was $195 \mathrm{~mm}$; comparison with the latest climate normal 1981-2010 shows that the mean annual air temperature was noticeably lower $\left(-5.1^{\circ} \mathrm{C}\right)$ than during the study period (Table 1$)$. Precipitation occurs mainly during winter and April, May, and June are the driest months. Over the course of the study period, both precipitation and mean air temperature were subject to considerable inter-annual variations reflecting Svalbard's maritime setting (Fig. S1 in the Supplement).

\section{Method}

\subsection{Field data}

In this study, an ensemble of active layer thaw depth, active layer and permafrost temperature, and active layer soil moisture data collected at the UNISCALM site was used (Table 2). The UNISCALM site consists of a $100 \mathrm{~m} \times 100 \mathrm{~m}$ grid with $10 \mathrm{~m}$ spacing for thaw depth observations (Christiansen and Humlum, 2008). Measurements of thaw depth progression and active layer thickness were performed by probing all 121 grid points with a metal rod 8 to 15 times during the thaw season from May to September each year (except for the year 2000, where only four measurements exist). Active layer temperature was measured by Tinytag miniature data loggers with temperature probes inserted directly into the sediment in a profile in the centre grid point of the UNISCALM site. The data set encompasses hourly temperature measurements at the ground surface $(0 \mathrm{~m})$ and at $0.1,0.2,0.5$, and $1.1 \mathrm{~m}$ depth. For the ground surface temperature measurements, two periods of missing data (31 August to 26 September 2001 and 26 April to 17 October 2004) were bridged using information from the next closest sensor at $0.1 \mathrm{~m}$ depth adopting a statistical data correction approach (Terink et al., 2010).

Permafrost temperatures and volumetric soil moisture content were recorded next to the UNISCALM grid. Hourly permafrost temperatures were available at 2.0, 3.0, 5.0, 7.0 and $9.85 \mathrm{~m}$ depth in borehole ASB-2 for the period between September 2008 and August 2014 from the Norwegian Permafrost database, NORPERM (Juliussen et al., 2010). Volumetric soil moisture content was recorded using a PR2 profile probe (Delta-T) with sensing elements at 0.1, 0.2, 0.3, $0.4,0.6$, and $1.0 \mathrm{~m}$ depth. Soil moisture was registered with a $3 \mathrm{~h}$ resolution for the period from July 2010 to August 2014. 
Table 1. Mean monthly and annual temperature $\left({ }^{\circ} \mathrm{C}\right)$ and precipitation $(\mathrm{mm})$ at Svalbard airport for the study period 2000-2014. Statistics (mean $\varnothing$ and annual sum $\Sigma$ ) for the latest climate normal 1981-2010 are included for comparison (data: Norwegian Meteorological Institute).

\begin{tabular}{|c|c|c|c|c|c|c|c|c|c|c|c|c|c|c|}
\hline & & & & & & & $2000-2$ & & & & & & & $1981-2010$ \\
\hline$T\left({ }^{\circ} \mathrm{C}\right)$ & $\begin{array}{r}\text { Jan } \\
-9.5\end{array}$ & $\begin{array}{r}\text { Feb } \\
-10.0\end{array}$ & $\begin{array}{r}\text { Mar } \\
-12.9\end{array}$ & $\begin{array}{r}\text { Apr } \\
-8.7\end{array}$ & $\begin{array}{l}\text { May } \\
-1.8\end{array}$ & $\begin{array}{r}\text { Jun } \\
+3.7\end{array}$ & $\begin{array}{r}\text { Jul } \\
+7.0\end{array}$ & $\begin{array}{r}\text { Aug } \\
+6.2\end{array}$ & $\begin{array}{r}\text { Sep } \\
+2.1\end{array}$ & $\begin{array}{r}\text { Oct } \\
-3.5\end{array}$ & $\begin{array}{l}\text { Nov } \\
-6.7\end{array}$ & $\begin{array}{r}\text { Dec } \\
-8.5\end{array}$ & $\begin{array}{r}\text { Mean, Sum } \\
\varnothing-3.6\end{array}$ & $\begin{array}{r}\text { Mean, Sum } \\
\varnothing-5.1\end{array}$ \\
\hline$P(\mathrm{~mm})$ & 20 & 12 & 15 & 9 & 8 & 7 & 21 & 20 & 22 & 21 & 19 & 22 & $\Sigma 195$ & $\Sigma 187$ \\
\hline
\end{tabular}

Table 2. Field data used (data: UNIS, NORPERM).

\begin{tabular}{lll}
\hline Method & Data & Period \\
\hline $\begin{array}{lll}\text { Tinytag individual thermistor probes con- } \\
\text { nected to miniature temperature loggers }\end{array}$ & $\begin{array}{l}\text { Ground surface temperature }(0.0 \mathrm{~m})\left({ }^{\circ} \mathrm{C}\right) \\
\text { Subsurface temperature }(-0.1,-0.2,-0.5, \\
-1.1 \mathrm{~m})\left({ }^{\circ} \mathrm{C}\right)\end{array}$ & 1 September 2000-31 August 2014 \\
\hline $\begin{array}{ll}\text { GeoPrecision thermistor string with data } \\
\text { logger }\end{array}$ & $\begin{array}{l}\text { Subsurface temperature }(-2.0,-3.0,-5.0, \\
-7.0,-9.85 \mathrm{~m})\left({ }^{\circ} \mathrm{C}\right)\end{array}$ & 17 September 2008-14 April 2014 \\
\hline Delta-T profile probe & $\begin{array}{l}\text { Soil moisture }(-0.1,-0.2,-0.3,-0.4, \\
-0.6,-1.0 \mathrm{~m})\left(\mathrm{m}^{3} \mathrm{~m}^{-3}\right)\end{array}$ & 1 July 2010-31 August 2014 \\
\hline Frost probing of CALM grid & Active layer thaw depth $(\mathrm{cm})$ & 1 September 2000-31 August 2014 \\
\hline
\end{tabular}

Temperature and soil moisture time series were converted into daily averages. Active layer thickness data were considered both for the centre grid node, which is the point nearest the location of the active layer temperature measurements, and for the average of all 121 UNISCALM grid points.

To quantify and evaluate the active layer response to thermal forcing, we consider a summer degree day index SDD = $\sqrt{\sum_{i} T_{i}}$ defined as the square root of the sum of positive daily ground surface (i.e. at $0 \mathrm{~m}$ ) temperatures $T_{i}$ from the onset of continuous thaw in spring until the start of active layer freeze-back in autumn (thereby restricting summed days $i$ to a season essentially corresponding to summer). Complementary to SDD, we define the sum of daily ground surface temperatures between the summers $T_{j}$ as winter degree days at the ground surface WDD $=\sqrt{\sum_{j} T_{j}}$ and use it as an indicator for the thermal conditions preceding the respective summer thaw. The consideration of all summer degree days this way has been proven useful to assess active layer response in particular to inter-annual temperature variability (Smith et al., 2009).

\subsection{Numerical model}

Simulations were performed with a recently developed numerical model, the Advanced Terrestrial Simulator (ATS), which can couple several thermal, hydrological, and hydrogeological processes for heat flux and water flow applicable to partially frozen ground in cold regions (Atchley et al., 2015; Coon et al., 2016; Painter et al., 2016). The focus of our study is on effects of soil moisture retention characteristics on subsurface heat and moisture propagation in the active layer and permafrost for a dry and relatively flat site; hence the physics presently considered are hydrogeological heat and flow processes. This includes accounting for partitioning of water between ice, liquid, and vapour phases, phasedependent thermal conduction, latent heat transfer, moisture migration due to phase change (wetting and cryosuction), and heat advection through the movement of water. The model solves a numerically discretized version of conservation equations for heat and water mass transport in porous media together with several constitutive relationships, including Darcy's law for partially saturated flow and accounting for phase partitioning by combined use of classical soil moisture retention curves and thermodynamic constraints derived from the Clausius-Clapeyron relation. Details of the underlying approach are provided in Frampton et al. (2011), Karra et al. (2014), and Painter (2011). Since moisture migration in the active layer is dominated by unsaturated flow for the site considered, and since retention characteristics are the main focus of this study, a brief summary of governing constitutive equations for phase partitioning as used by the model are provided in the following.

Partitioning between ice, liquid, and vapour phase saturation, denoted by $s_{\mathrm{i}}, s_{1}$, and $s_{\mathrm{g}}$, respectively, and constrained by $s_{\mathrm{i}}+s_{1}+s_{\mathrm{g}}=1$, is achieved by simultaneously inverting two constitutive relationships each relating liquid saturation with ice saturation as (Karra et al., 2014)

$$
\begin{aligned}
& s_{1}=\left(1-s_{i}\right) S_{*}\left(P_{\mathrm{cgl}}\right) \\
& s_{1}=S_{*}\left[-\beta \rho_{\mathrm{i}} h_{0} \vartheta H(-\vartheta)+S_{*}^{-1}\left(s_{1}+s_{\mathrm{i}}\right)\right],
\end{aligned}
$$

where $S_{*}$ is the retention curve for unfrozen liquid-gas phases, $\mathrm{P}_{\mathrm{cgl}}(\mathrm{Pa})$ is the liquid-gas capillary pressure, $\beta(-)$ 
is the ratio of ice-liquid to liquid-air surface tensions, $\rho_{\mathrm{i}}$ $\left(\mathrm{kg} \mathrm{m}^{-3}\right)$ is the mass density of ice, $h_{0}=334\left(\mathrm{~kJ} \mathrm{~kg}^{-1}\right)$ is the enthalpy of fusion, and $T(\mathrm{~K})$ is temperature with $\vartheta=$ $\left(T-T_{0}\right) / T_{0}(-)$ and $T_{0}=273.15 \mathrm{~K}$. The Heaviside function $H$ is used to make Eq. (1b) applicable to both frozen and unfrozen conditions. The first relation Eq. (1a) expresses a retention curve for unfrozen water where the available pore space is reduced by the fraction of ice present. The second relation Eq. (1b) describes liquid saturation as a function of total water content, where the first term in the square brackets corresponds to the capillary pressure between ice-liquid phases when gas is absent (saturated conditions), and the second term is the addition to the ice-liquid capillary pressure when gas is present (unsaturated conditions). In our study, the retention curve $S_{*}$ is expressed using the van Genuchten (1980) model,

$S_{*}\left(P_{\mathrm{c}}\right)=S_{\mathrm{r}}+\left(1-S_{\mathrm{r}}\right)\left[1+\left(\alpha P_{\mathrm{c}}\right)^{n}\right]^{-m}$ if $P_{\mathrm{c}}>$

$S_{*}\left(P_{\mathrm{c}}\right)=1$ if $P_{\mathrm{c}} \leq 0$,

combined with the Mualem (1976) model for rescaling liquid phase permeability:

$k_{\mathrm{rl}}=\left(s_{1}\right)^{\frac{1}{2}}\left[1-\left(1-\left(s_{1}\right)^{\frac{1}{m}}\right)^{m}\right]^{2}$,

where $S_{\mathrm{r}}(-)$ is residual saturation, $P_{\mathrm{c}}(\mathrm{Pa})$ capillary pressure, and $\alpha\left(\mathrm{Pa}^{-1}\right)$ and $m=1-1 / n(-)$ are model parameters. The exponent $m$ controls the shape of the soil moisture retention curve and can be related to the pore size distribution of the texture (Mualem, 1976; van Genuchten, 1980), where larger values generally correspond to smaller pore size variability, i.e. to well-sorted textures.

\subsection{Model configurations}

The model domain was configured as a 1-D vertical column of the subsurface, with top corresponding to the ground surface and bottom at a depth of $10 \mathrm{~m}$, and with a $0.1 \mathrm{~m}$ resolution of cell heights. A depth of $10 \mathrm{~m}$ was chosen since this corresponds to the approximate depth of zero annual amplitude measured at the UNISCALM site. Given the comparatively homogeneous soil composition at the site, the entire model domain was assigned the physical and thermal properties of silt loam (Table 3). Different soil moisture retention characteristics were investigated by varying the parameters $\alpha$ and $m$ of the van Genuchten model Eq. (2), all within bounds applicable to silt loam (Table 4 and Fig. 2). In all scenarios, residual saturation $S_{\mathrm{r}}$ is set to zero, consistent with commonly adopted practice for silty soils (Destouni, 1991; Painter and Karra, 2014; Wang et al., 2015; Watanabe and Wake, 2009; Weismüller et al., 2011). A reference case is first defined using average values $\left(\alpha=8 \times 10^{-4} \mathrm{~Pa}^{-1}\right.$ and $m=0.19)$ obtained from the UNSODA soil hydraulic database (Ghanbarian-Alavijrh et al., 2010) for silt loam soils. Thereafter, both $\alpha$ and $m$ were varied independently by

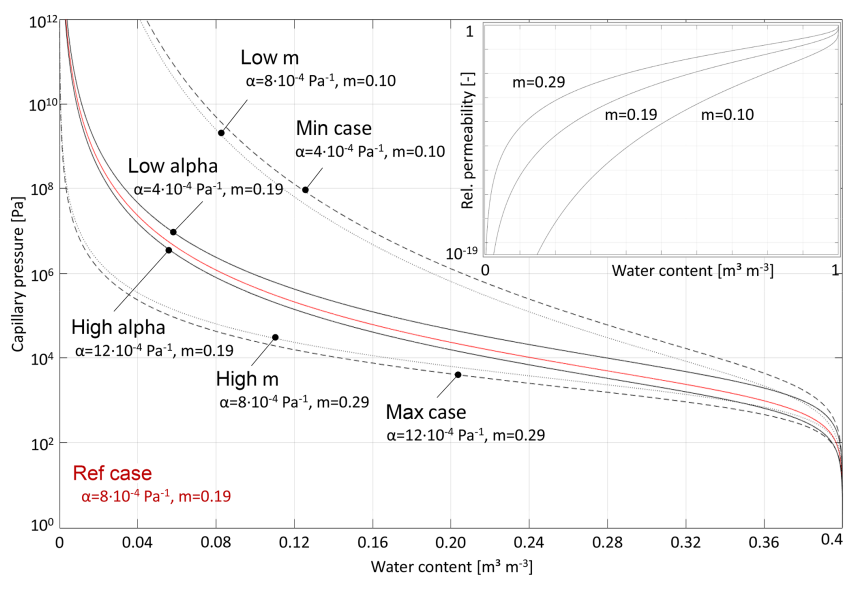

Figure 2. Retention curves $S_{*}$ described by the van Genuchten model (Eq. 2) and as used in the different model scenarios; residual saturation set to zero for all cases. (Inset) Relative permeability described by the Mualem model (Eq. 3).

$\pm 50 \%$ with respect to the reference case, resulting in model scenarios labelled as high/low $\alpha$ and high/low $m$ (Table 4). Two additional scenarios, "max case" and "min case", represent the high and low ends of the parameter range by combining high $\alpha$ with high $m$, and low $\alpha$ with low $m$, respectively. All of these parameter values are within the range of the variation for silt loam reported in the UNSODA database and in literature (Destouni, 1991; Wang et al., 2015; Watanabe and Wake, 2009).

Given that each combination of van Genuchten parameters will result in different soil moisture profiles, each simulation test case was set-up to attain unique ice-liquid-gas states. Still, despite the systematic approach of testing relevant parameter combinations, note that any potential nonlinearities arising from untested combinations within the parameter space remain unconsidered in this analysis. To be consistent with site conditions, each simulation case was initialized with unsaturated frozen ground to a depth of about $-1.2 \mathrm{~m}$ and saturated below. This was done by assigning the ground surface a pressure of about $-200 \mathrm{hPa}$, linearly interpolating to the bottom of the unfrozen model domain, and then freezing the column.

Thereafter, an annually periodic steady state was obtained by running multiple iterations (i.e. a spin-up) using a smoothed version of the observed ground surface temperature time series as surface boundary condition. The convergence criterion was set as a maximum temperature difference between two consecutive iterations to be less than $0.1{ }^{\circ} \mathrm{C}$. This yielded an active layer thickness, defined by the $0^{\circ} \mathrm{C}$ isotherm, of approximately $1 \mathrm{~m}$ for most cases, which is also consistent with site conditions.

The simulation investigations were then carried out by directly adopting the daily ground surface temperature time series (i.e. temperatures measured at $0 \mathrm{~m}$ over the time period 
Table 3. Physical and thermal subsurface properties used in model simulations.

\begin{tabular}{llrl}
\hline Material property & Units & Value & Reference \\
\hline Residual saturation & - & 0 & e.g. Destouni (1991), Painter and Karra (2014), Watanabe and Wake (2009) \\
Porosity & - & 0.4 & e.g. Fitts (2013), Schwartz and Zhang (2003) \\
Permeability & $\mathrm{m}^{2}$ & $10^{-12}$ & e.g. Freeze and Cherry (1979) \\
Density & 2650 & e.g. Andersland and Ladanyi (1994) \\
Heat capacity & $\mathrm{kg} \mathrm{m}^{-3}$ & 850 & e.g. Andersland and Ladanyi (1994), Fitts (2013), Ochsner et al. (2001) \\
Thermal conductivity (saturated) & $\mathrm{J} \mathrm{kg} \mathrm{m}^{-1} \mathrm{~K}^{-1}$ & 1.7 & e.g. Woo (2012) \\
Thermal conductivity (dry) & $\mathrm{W} \mathrm{m}^{-1} \mathrm{~K}^{-1}$ & 0.27 & e.g. Woo (2012) \\
\hline
\end{tabular}

2000-2014) as the top boundary condition of the model. The bottom boundary was assigned a linearly increasing temperature trend from $-6.05^{\circ} \mathrm{C}$ (September 2000 ) to $-5.4^{\circ} \mathrm{C}$ (August 2014), consistent with the increasing temperature trend of $0.05^{\circ} \mathrm{C} \mathrm{yr}^{-1}$ observed for the time period 2008 until 2014 at depth $-9.85 \mathrm{~m}$.

Lateral water fluxes through and infiltration into the system were neglected and no-flow boundaries were assigned to all faces of the model domain. While the importance of groundwater flow for permafrost thaw patterns has been shown in previous studies, those investigations were performed in different environmental settings, such as in watersaturated lowland Siberian tundra (Helbig et al., 2013), generic nested groundwater-flow systems (McKenzie and Voss, 2013), or subarctic peat plateaus characterized by numerous thermokarst lakes and fens in the sporadic permafrost zone of northern Sweden (Sjöberg et al., 2016). While recognizing that flowing water can have considerable thermal effects on active layer processes, its exclusion is considered an appropriate assumption for the dry UNISCALM site where melt water runoff from the valley is significantly diverted into the Isdammen water reservoir (see Sect. 2). Infiltration was determined to be of minor importance based on field evidence for a shallow snow cover of $20-30 \mathrm{~cm}$ (Christiansen and Humlum, 2008), large wind transport of snow and high evaporation and sublimation rates (Westermann et al., 2010), combined with findings from a previous modelling study indicating that inter-annual active layer variation at the site is largely unaffected by infiltration derived from the small amounts of early spring snowmelt and summer precipitation (Schuh, 2015).

The simulated results for the different cases were then evaluated in the context of available field data such as active layer thickness, subsurface ground temperature and soil moisture. The simulated active layer thickness was defined as the deepest numerically calculated $0^{\circ} \mathrm{C}$ isotherm for each year.

\section{Results}

\subsection{Active layer thickness and subsurface temperatures}

Model results show that the different assumptions regarding soil water retention properties impact subsurface temperatures and active layer thickness (ALT). The modelled ALT ranged from 90 to $130 \mathrm{~cm}$ considering all scenarios and years (Table 5). Cases with a small value for the van Genuchten parameter $m$ ("low $m$ " and "min case") generally had ALTs in the range $100-130 \mathrm{~cm}$, somewhat larger than moderate or high values of $m$, which had ALTs in the range 90 to $110 \mathrm{~cm}$ (e.g. "ref case" and "high $m$ "). Accordingly, the mean modelled ALT over the study period was $118-119 \mathrm{~cm}$ for the cases assuming a small value for $m$ and $99-103 \mathrm{~cm}$ for the other cases. Overall, the smallest ALT was simulated for the years 2005 and 2008, and the largest for the years 2006, 2013, and 2014. This compares well with the measured ALTs at the UNISCALM grid ranging from 74 to $110 \mathrm{~cm}$ depending on year. The smallest ALT occurred in 2005 and the deepest in 2008, with a mean of $98 \mathrm{~cm}$ over the entire time period (Table 5).

Inter-annual variation in simulated ALT was comparatively small for most of the scenarios with standard deviations of about $5-6 \mathrm{~cm}$. For scenarios with low value for $m$, inter-annual variation in ALT was slightly higher with standard deviations of about $8-9 \mathrm{~cm}$. The standard deviations based on measured thaw depth were close to $8 \mathrm{~cm}$, both for the grid average and only considering the centre probing location. Depending on scenario, a trend of increasing ALT varied from 0.3 to $0.8 \mathrm{~cm} \mathrm{yr}^{-1}$ for the entire study period, which can be compared to the trend of $0.8 \mathrm{~cm} \mathrm{yr}^{-1}$ obtained from the UNISCALM grid measurements average (Table 5).

The observed tendency of increasing ground temperatures (Table 6) over the study period was represented well by the simulations, irrespective of the chosen soil water retention parameters, where the average of all scenarios resulted in a trend of $0.25^{\circ} \mathrm{Cyr}^{-1}$ at $0.1 \mathrm{~m}$ depth, and decreasing to $0.05^{\circ} \mathrm{C} \mathrm{yr}^{-1}$ at $9.85 \mathrm{~m}$ depth, consistent with the corresponding trends obtained from the measured active layer and permafrost temperatures. Also, note that the observed increase in ground surface temperature can be ascribed exclusively to increasing winter temperatures, since the trend in sum- 
Table 4. Van Genuchten parameters $\alpha$ and $m$ (Eq. 2) consistent with silt textures and as assigned in the seven model scenarios.

\begin{tabular}{lrrrrrrr}
\hline & Ref case & High alpha & Low alpha & High $m$ & Low $m$ & Max case & Min case \\
\hline van Genuchten $\alpha\left(\mathrm{Pa}^{-1}\right)$ & $8 \times 10^{-4}$ & $12 \times 10^{-4}$ & $4 \times 10^{-4}$ & $8 \times 10^{-4}$ & $8 \times 10^{-4}$ & $12 \times 10^{-4}$ & $4 \times 10^{-4}$ \\
van Genuchten $m(-)$ & 0.19 & 0.19 & 0.19 & 0.29 & 0.10 & 0.29 & 0.10 \\
\hline
\end{tabular}

Table 5. Active layer thickness (ALT) for the study period 2000-2014 and corresponding statistics, as measured at the UNISCALM grid (average of all grid points and also the centre location, which is nearest the temperature logger) and as obtained from simulations.

\begin{tabular}{|c|c|c|c|c|c|c|c|c|c|}
\hline \multirow[b]{2}{*}{ Year } & \multicolumn{2}{|c|}{ Measured ALT $(\mathrm{cm})$ UNISCALM site } & \multicolumn{7}{|c|}{ Modelled ALT $(\mathrm{cm})$ Different soil moisture retention properties } \\
\hline & Grid average & Grid centre & Ref case & High alpha & Low alpha & High $m$ & Low $m$ & Max case & Min case \\
\hline 2000 & 95 & 100 & 100 & 100 & 100 & 100 & 110 & 100 & 110 \\
\hline 2001 & 99 & 102 & 100 & 110 & 110 & 110 & 120 & 100 & 130 \\
\hline 2002 & 96 & 100 & 100 & 100 & 100 & 100 & 120 & 100 & 120 \\
\hline 2003 & 93 & 99 & 100 & 100 & 100 & 100 & 110 & 90 & 110 \\
\hline 2004 & 91 & 99 & 100 & 100 & 100 & 100 & 120 & 100 & 120 \\
\hline 2005 & 74 & 79 & 100 & 100 & 100 & 90 & 110 & 90 & 110 \\
\hline 2006 & 100 & 104 & 110 & 110 & 110 & 110 & 130 & 100 & 130 \\
\hline 2007 & 105 & 106 & 100 & 100 & 100 & 100 & 110 & 100 & 110 \\
\hline 2008 & 110 & 116 & 90 & 90 & 90 & 90 & 100 & 90 & 100 \\
\hline 2009 & 100 & 106 & 100 & 100 & 100 & 100 & 120 & 100 & 120 \\
\hline 2010 & 100 & 110 & 100 & 100 & 100 & 100 & 120 & 100 & 120 \\
\hline 2011 & 101 & 104 & 110 & 110 & 110 & 100 & 120 & 100 & 120 \\
\hline 2012 & 101 & 107 & 100 & 100 & 100 & 100 & 120 & 100 & 120 \\
\hline 2013 & 103 & 111 & 110 & 110 & 110 & 110 & 130 & 110 & 130 \\
\hline 2014 & 103 & 110 & 110 & 110 & 110 & 110 & 130 & 110 & 130 \\
\hline \multicolumn{10}{|c|}{ Statistics for time period 2000-2014 } \\
\hline Min & 74 & 79 & 90 & 90 & 90 & 90 & 100 & 90 & 100 \\
\hline Max & 110 & 116 & 110 & 110 & 110 & 110 & 130 & 110 & 130 \\
\hline Mean & 98 & 104 & 102 & 103 & 103 & 101 & 118 & 99 & 119 \\
\hline SD & 7.9 & 8.1 & 5.4 & 5.7 & 5.7 & 6.2 & 8.3 & 5.7 & 8.8 \\
\hline Trend $\left(\mathrm{cm} \mathrm{yr}^{-1}\right)$ & 0.8 & 1.0 & 0.5 & 0.3 & 0.3 & 0.3 & 0.8 & 0.6 & 0.6 \\
\hline
\end{tabular}

mer temperature on the ground surface was essentially stable $\left(-0.05^{\circ} \mathrm{C} \mathrm{yr}^{-1}\right)$ over the study period, in contrast to the relatively strong increase in winter ground surface temperature $\left(+0.25^{\circ} \mathrm{C} \mathrm{yr}^{-1}\right)$.

\subsection{Ice and water content}

By model design, the permafrost was fully saturated below a depth of about $1.2 \mathrm{~m}$ in all scenarios. However, depending on the retention curve parametrization, the different scenarios exhibit different fractions of ice and unfrozen water content in the permafrost. The scenarios with large $m=0.29$ ("high $m$ " and "max case") have highest volumetric ice contents of $39 \%$, followed by scenarios with intermediate $m=0.19$ ("high alpha", "ref case", and "low alpha") with approx. $36 \%$ ice content, and scenarios with $m=0.1$ ("low alpha" and "min case") with only $26 \%$ ice content (Fig. 3). The remaining fraction to full saturation, i.e. 1,4 , and $14 \%$, respectively, consists of unfrozen liquid water (porosity was assigned to $40 \%$, see Table 3 , consistent with field conditions).
Although no additional infiltration is imposed so that the total water mass in each modelled system is constant over time, the retention curves yield different phase partitioning resulting in different initial total water mass. During freezing of the active layer, water becomes repartitioned according to phase state and migrates by cryosuction, and both ice content and distribution vary considerably between scenarios (Fig. 3). Total ice content is observed to be mainly a function of $\alpha$ in the retention curve (Eq. 2) with lower values resulting in higher ice content; the largest total ice content was obtained for the case "low alpha" (30-35\%), followed by "ref case" and "min case" (25-30\%), "high $m$ ", "low $m$ ", "high alpha" (15-25\%), and "max case" (12-18\%). However, the ice distribution and spatial layering with depth was mainly a function of $m$. For low values $m=0.1$ no distinct ice layering was observed, instead the ice distribution was relatively homogeneous throughout the active layer (Fig. 3c). For the other cases, layers of increased ice content developed more clearly with increasing $m$, typically with a tendency of a narrow layer of higher ice content just below the ground surface as well as within a layer above the permafrost table. This stratification was most pronounced for large $m=0.29$ 
Table 6. Subsurface temperature trends $\left[{ }^{\circ} \mathrm{C} \mathrm{yr}^{-1}\right]$ as recorded and modelled (mean of all scenarios). Trends in the active layer (down to $1.1 \mathrm{~m}$ depth) are calculated for the period September 2000-August 2014, and trends in the permafrost (from 2.0 to $9.85 \mathrm{~m}$ depth) for the period September 2008-August 2014. Summer is here defined as the period of continuous positive temperatures during the thaw season and winter as the remaining part of the year.

\begin{tabular}{|c|c|c|c|c|c|c|c|c|c|c|c|}
\hline \multirow[b]{2}{*}{ Depth (m) } & \multicolumn{10}{|c|}{ Trend $\left({ }^{\circ} \mathrm{Cyr}^{-1}\right)$} & \multirow[b]{2}{*}{9.85} \\
\hline & 0.00 (summer) & 0.00 (winter) & 0.10 & 0.20 & 0.50 & 1.10 & 2.00 & 3.00 & 5.00 & 7.00 & \\
\hline Observed & -0.05 & 0.25 & 0.23 & 0.26 & 0.19 & 0.17 & 0.14 & 0.15 & 0.11 & 0.07 & 0.05 \\
\hline Modelled (mean of all scenarios) & NA & NA & 0.25 & 0.24 & 0.2 & 0.16 & 0.13 & 0.11 & 0.09 & 0.07 & 0.05 \\
\hline
\end{tabular}

$\mathrm{NA}=$ not available

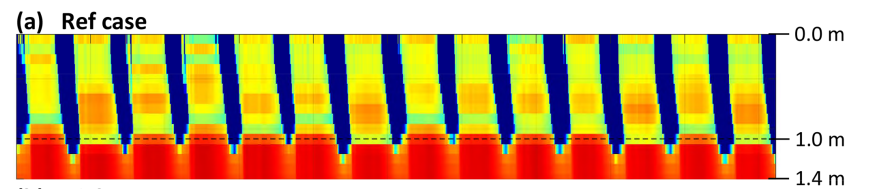

(b) High $\mathrm{m}$

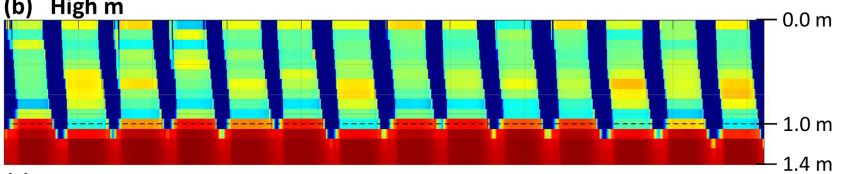

(c) Low $\mathrm{m}$

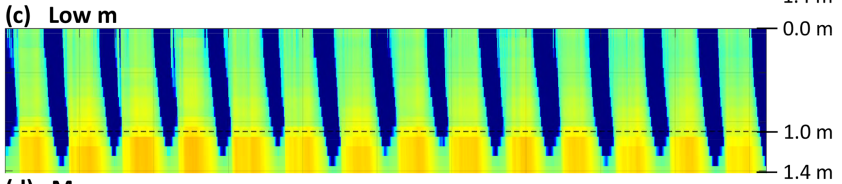

(d) Max case

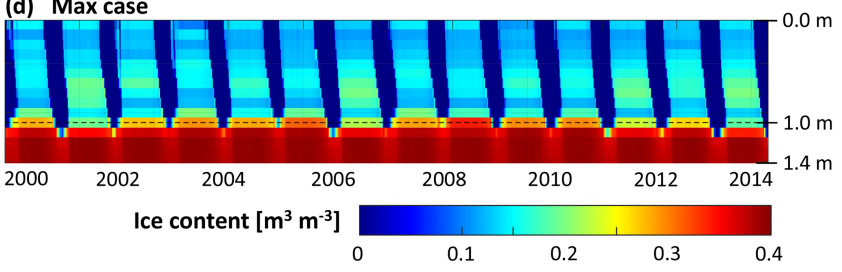

Figure 3. Ice content $\left(\mathrm{m}^{3} \mathrm{~m}^{-3}\right)$ in the active layer and upper permafrost over the study period as simulated in four selected scenarios.

(Fig. 3d). Note also that the vertical position and depth extent of the layers vary over time for all cases, indicating different ice redistributions occurring in each freeze-up season.

During summer, the simulated water content in the approximate centre of the active layer, i.e. at $0.6 \mathrm{~m}$ depth, was between 15 and $38 \%$ depending on model scenario (Fig. 4c), with slight increase with depth (Fig. 4d). The increase in water content generally coincided with the onset of thaw in spring and with the location of the thawing front. Note that the timing of increase and subsequent drop of the water content deteriorates with depth. Except for scenarios assuming a small value $m=0.1$ (e.g. "min case"), the model cases show a delayed increase and a premature and prolonged decrease in water content in the lowermost active layer (i.e. at $1.0 \mathrm{~m}$ depth, Fig. 4d).

Moderate peaks in measured water content can be seen in the field measurements at depth $0.1 \mathrm{~m}$ (Fig. 4b, black line), which are significantly attenuated already at 0.6 and $1.0 \mathrm{~m}$ depth (Fig. 4c and d, black line). These could correspond to brief infiltration events, for example caused by snow melt at the onset of thaw, confined to the uppermost thawed soil layers, while parts below remain frozen (see temperatures at 0.5 and $1.1 \mathrm{~m}$ depth, Fig. 4a), thereby momentarily saturating the top part of the active layer. Aside from the peaks at $0.1 \mathrm{~m}$ depth, the scenarios "max case" and "high $m$ " reflect the observed total water content in the thawed active layer (15-25\%) to a high degree, whereas the other scenarios (e.g. "min case") overestimated it considerably. In winter, the amount of unfrozen water seems to be best represented by scenarios using an average value $m=0.19$, e.g. "ref case". Water contents for scenarios "low/high $\alpha$ " and "low/high $m$ " lie within the range of, and show the same behaviour as, scenarios "min case", "ref case", and "max case" (not shown).

\section{Discussion}

\subsection{Soil moisture and ground ice distribution}

Even for the same soil type considered (silt loam), the specific choice of retention parameters consistent within the range applicable for that texture class, as exemplified by the seven simulation cases studied here (Table 3), clearly has an influence on the amount and redistribution of both liquid water and ice in the active layer with its annual freeze-thaw cycles (Figs. 3 and 4). The water retention parameters tested in the different scenarios also impacted the unfrozen water content in the active layer as well as in the permafrost. The parameter $\alpha$ normalizes capillary pressure (Eq. 2) so that the main effect of a decrease or increase in $\alpha$ results in a general shift of the retention curve up or down, resulting in a higher or lower overall liquid saturation, respectively (see Fig. 2). This parameter is varied by almost one order of magnitude between the different cases, causing a maximum difference in water content of about $10 \%$ in the active layer (corresponding to a change of about $25 \%$ in terms of saturation).

The parameter $m$ controls the overall shape and slopes of the retention curve. This way, it is significant for cryosuction and thus redistribution of ice in the active layer during freeze-up. The retention curves with small values $m=0.1$ exhibit relatively smooth overall slopes even for low satu- 


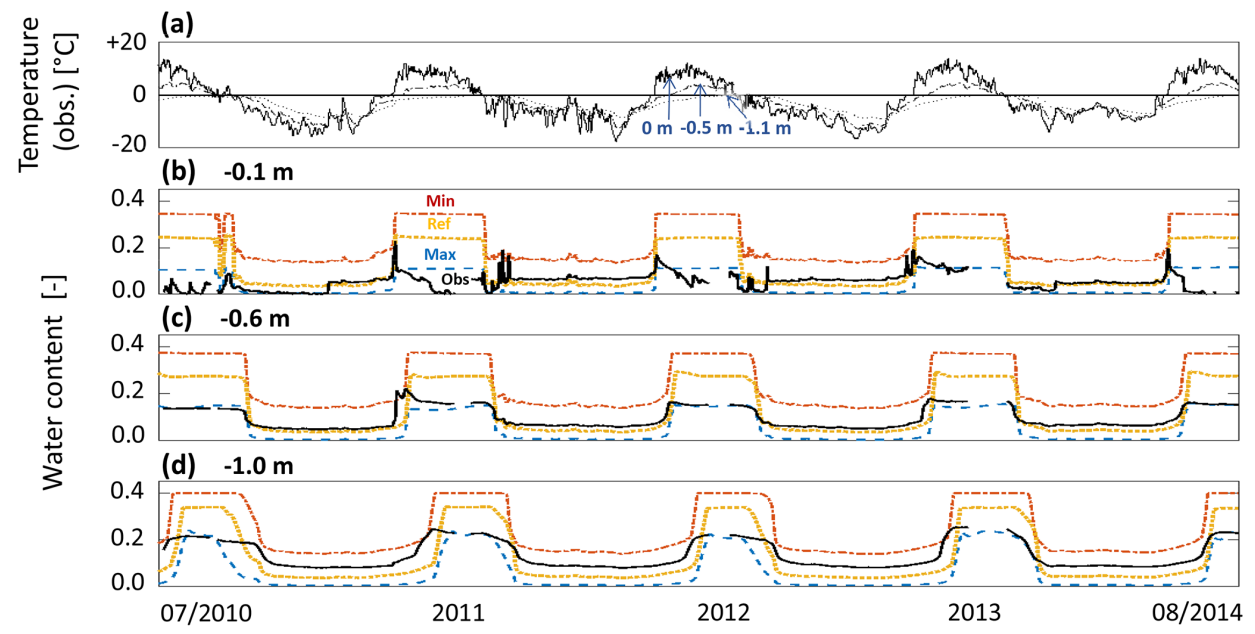

Figure 4. (a) Daily measured ground temperatures on the surface $0 \mathrm{~m}$ (solid) and at depths $0.5 \mathrm{~m}$ (dashed) and $1.1 \mathrm{~m}$ (dotted) between July 2010 and August 2014. Also volumetric water content at depths (b) $0.1 \mathrm{~m}$, (c) $0.6 \mathrm{~m}$, and (d) $1.0 \mathrm{~m}$ as observed (solid black) and modelled (showing ref case, min case and max case in yellow, red and blue respectively). The remaining simulation cases (not shown) reside within the limits of the min and max cases.

rations (see Fig. 2), and do not result in high cryosuction effects. Instead, scenarios with high $m=0.29$, and comparatively steeper slopes for low saturations, result in the strongest changes in capillary pressure and hence stronger cryosuction. A reason for this is the respective fraction of water that remains unfrozen even at temperatures below $0{ }^{\circ} \mathrm{C}$. Given a certain soil water content in the active layer, a drop in subsurface temperature of about $10^{\circ} \mathrm{C}$, as typically observed in winter, results in an increase in capillary pressure since liquid water undergoes a phase change to ice. The liquid water content is thereby reduced, resulting in an effective drying out of the pore space and yielding a hydraulic gradient towards the freezing front. For retention curves with high $m$ value displaying a higher non-linearity at low saturations, this increase in capillary pressure leads to a small fraction of unfrozen water $(\sim 1 \%$ for $m=0.29)$. In contrast, for the same increase in capillary pressure, retention curves with low $m$ value yield higher unfrozen water contents $(\sim 14 \%$ for $m=0.1$ ). As a consequence, cryosuction and the resulting moisture migration to the freezing front is stronger for scenarios assuming higher $m$ since such cases undergo stronger phase change and stronger effective drying of the pore space.

This is reflected in the simulated ground ice redistribution pattern, where scenarios with high $m$ values ("high $m$ ", "max case") typically showed well-defined layers of ice in the upper and lower parts of the active layer, whereas cases with low $m$ values ("low $m$ ", "min case") did not exhibit such a distinct variable ice pattern (Fig. 3c). The parameter $m$ relates to physical soil properties, specifically the pore size distribution and pore connectivity/tortuosity, where large $m$ is generally considered to correspond to a small variability in pore size distribution, i.e. corresponding more to a wellsorted texture. Note also that parameter $m$ controls relative permeability in the Mualem model (Eq. 3 and Fig. 2, inset) and hence hydraulic conductivity. At the UNISCALM site, the sediment has been described as a well-sorted loess sediment and thus may be more consistent with larger $m$ values. Furthermore, the comparison against soil water content in the active layer (Fig. 4) revealed that scenarios using an average $m=0.19$ or large $m=0.29$ seemed more consistent with observed unfrozen water content during the frozen period. In scenario "max case" the soil water content during the thaw period is lowest of all scenarios, and at a level which is consistent with field measurements $(\sim 10-20 \%)$.

Based on simulated results, we infer that the higher ice content in the top-most parts of the active layer developed by cryosuction caused by the downward moving freezing front, whereas the ice in the deeper parts of the active layer may be a combination of cryosuction-induced moisture migration together with water percolating down by gravity during the thaw period. Here the cryosuction effect may either counteract percolation or enhance it, depending on if oneor two-sided freezing occurs. Considering the downwardmoving freezing front from the ground surface, this should cause a cryosuction-induced moisture migration towards the freezing front, i.e. move moisture upwards and thereby work against gravity-driven percolation flow (and creating a higher ice content in the upper part of the active layer). A freezing front moving upwards from the top permafrost would, however, cause a cryosuction-induced moisture migration downwards, thereby working together with percolation flow (and causing a middle part of the active layer with only little ice). For two-sided freezing, the rates of heat propagation, which in turn would also depend on the variability of the surface temperature and the thermal state of the permafrost below, would govern the strength of cryosuction-induced moisture 
migration from the respective fronts and their net effect on moisture movement combined with percolation in the active layer. Considering the general spread of increased ice content at approximate depths $0.5-1.0 \mathrm{~m}$ (e.g. Fig. 3a), cryosuctioninduced moisture migration may be occurring in both directions, i.e. consistent with two-sided freezing, at least for cases with moderate to high values of $m$.

Field investigations indicate that downward freezing from the ground surface may cause ice lenses to form mainly in the upper active layer, and two-sided freezing may cause segregated ice and a drier middle active layer to form (French, 2007). Also, an augmented amount of ice lenses near the bottom of the active layer and top of permafrost is generally interpreted as ice segregation through upward freezing from the permafrost table or caused by percolation and moisture migration down to the permafrost (Cheng, 1983; Mackay, 1972). At the UNISCALM site, lenticular cryostructures at the top of the permafrost have been observed (Cable et al., 2017; Gilbert, 2014), and recent sediment core retrieval in March 2015 on a river terrace near the UNISCALM site showed increased ice lenses in the upper active layer as well as at the top of the permafrost, whereas the middle active layer was comparably dry showing further evidence for both downward and upward freezing. Boike et al. (1998) identified two-sided freezing at a comparable study site in Siberia using frost probing and water content information. It therefore seems likely that two-sided freezing occurs at the UNISCALM site, even if the downward freezing component is dominant.

\subsection{Thaw progression and refreezing}

Soil moisture and ground ice distribution impact subsurface temperatures and temperature gradients since heat propagation into and out of the ground is largely controlled by both phase-dependent thermal conductivity and latent heat transfer. The model results showed that scenarios assuming a small $m$ value ("low $m$ ", "min case") resulted in greater ALT and greater inter-annual variations in ALT, as well as larger increasing trends of ALT over the study period (Table 5). The timing and duration of thaw in the upper active layer was essentially the same for all cases (Fig. 4b), whereas it was delayed and underestimated in the lower active layer for cases with large $m$ value (Fig. 4d). A more detailed consideration of the thawing process, here exemplified for year 2011 (Table 7), further showed that to thaw the upper $1 \mathrm{~m}$ of the model domain, 58-60 days were required in scenarios using small $m$ values ("low $m$ ", "min case"), 74-76 days in scenarios using average $m$ values ("ref case", "high alpha", "low alpha"), and 78-85 days in scenarios using large $m$ values ("high $m$ ", "max case"). This is altogether evidence for a more efficient heat propagation into the ground for scenarios assuming a low $m$ value, and thereby a clearer reflection of the influence of ground surface temperature dynamics on the deeper subsurface.
Table 7 also helps understand the different thaw progression rates by summarizing the prevailing moisture conditions in the upper $1 \mathrm{~m}$ of the model domain (essentially corresponding to the active layer) at the end of winter and just prior to the onset of thaw in 2011. An effective thermal conductivity $\kappa_{\mathrm{e}}$ was calculated based on the fraction of ice, water, and air content (excluding the soil matrix) at that point in time, and the total latent heat $L$ was determined directly from the respective ice mass. Accordingly, effective thermal conductivities clearly reflect the phase partitioning, with lowest $\kappa_{\mathrm{e}}=0.34$ and $\kappa_{\mathrm{e}}=0.47 \mathrm{~J} \mathrm{~kg}^{-1} \mathrm{~K}^{-1}$ found for settings with largest air fractions of $24 \%$ ("max case") and $18 \%$ ("high $m$ ”) respectively, and highest $\kappa_{\mathrm{e}}=0.73 \mathrm{~J} \mathrm{~kg}^{-1} \mathrm{~K}^{-1}$ occurring for a nearly ice-saturated setting with small air content of $3 \%$ ("low alpha"). The latent heat buffer depended on the simulation case and ranged from $L=20$ ("max case") to $L=42 \mathrm{MJ}$ ("low alpha"). The thaw rate is, however, highest in scenarios "low $m$ " and "min case", which are combining medium to high effective thermal conductivity $\left(\kappa_{\mathrm{e}}=0.54\right.$ to $0.60 \mathrm{~J} \mathrm{~kg}^{-1} \mathrm{~K}^{-1}$ ) with medium to low latent heat consumption $(L=27$ to $31 \mathrm{MJ})$. In contrast, as shown in scenario "max case", heat propagation can be severely hindered by high air content resulting in low effective thermal conductivity, even if it only contains a small amount of ice ( $L=20 \mathrm{MJ}$ ). For the active layer freeze-back in autumn the same processes apply in reverse, i.e. heat flux is inverted flowing from the subsurface up and out of the ground. For scenario "max case", this implies a slow progression of the freezing front, visible in the gentle drop of liquid water content simulated in the lower active layer (Fig. 4d). However, upward freezing from the permafrost table causes an earlier freeze-back of the active layer bottom, so that, despite a less efficient heat transfer in some cases, active layer freeze-back is completed at about the same time in all scenarios.

Furthermore, model simulations show that not only the amount of soil moisture, but also the distribution of ice within the active layer impacts the progression of the thawing front. Figure 5 compares the ice content profile before the onset of thaw in 2011 to the respective thaw rate when the ground surface temperatures become positive. As shown previously (see Fig. 3), model scenarios "ref case" (black), "high $m$ " (green), and "max case" (orange) resulted in a distinct stratification of ice, whereas "low $m$ " (blue) shows almost a linear increase in ice content towards the permafrost table (Fig. 5a). In all scenarios, thawing the upper $10 \mathrm{~cm}$ of the ground occurs at a relatively low rate between 1.3 and $1.4 \mathrm{~cm} \mathrm{~d}^{-1}$ (Fig. 5b), mainly because air temperatures are still low, but also because of latent heat consumption due to the increased ice content in the thin layer just beneath the surface. Once the thawing front passes the ice layer at $5 \mathrm{~cm}$ depth, the thaw rate increases to its maximum of $5 \mathrm{~cm} \mathrm{~d}^{-1}$, fuelled by markedly increasing air temperatures (not shown) and regardless of the respective soil moisture content. Below $20 \mathrm{~cm}$ depth, all scenarios show a generally decreasing thaw rate, but with notably case-specific differences only between 40 and $60 \mathrm{~cm}$ 
Table 7. Simulated thaw progression to $1 \mathrm{~m}$ depth including the water phase state after the onset of positive ground surface temperatures in May 2011.

\begin{tabular}{|c|c|c|c|c|c|c|c|}
\hline $\begin{array}{l}\text { Simulation } \\
\text { scenario }\end{array}$ & $\begin{array}{l}\text { Time to thaw } \\
1 \mathrm{~m} \text { depth (days) }\end{array}$ & $\begin{array}{l}\text { Mean thaw rate } \\
\qquad\left(\mathrm{cm} \mathrm{d}^{-1}\right)\end{array}$ & $\begin{array}{r}\text { Vol. ice } \\
\text { content (-) }\end{array}$ & $\begin{array}{r}\text { Vol. unfrozen } \\
\text { water content (-) }\end{array}$ & $\begin{array}{r}\text { Vol. air } \\
\text { content (-) }\end{array}$ & $\begin{array}{l}\text { Effective therm. cond. } \\
\qquad K_{\mathrm{e}}\left(\mathrm{J} \mathrm{kg}^{-1} \mathrm{~K}^{-1}\right)\end{array}$ & $\begin{array}{r}\text { Total latent } \\
\text { heat } L(\mathrm{MJ})\end{array}$ \\
\hline Ref case & 75 & 1.3 & 0.25 & 0.05 & 0.10 & 0.58 & 33.6 \\
\hline High alpha & 74 & 1.4 & 0.22 & 0.04 & 0.14 & 0.50 & 28.7 \\
\hline Low alpha & 76 & 1.3 & 0.32 & 0.06 & 0.03 & 0.73 & 42.3 \\
\hline High $m$ & 78 & 1.3 & 0.21 & 0.01 & 0.18 & 0.47 & 28.1 \\
\hline Low $m$ & 58 & 1.7 & 0.21 & 0.14 & 0.05 & 0.54 & 27.4 \\
\hline Max case & 85 & 1.2 & 0.15 & 0.01 & 0.24 & 0.34 & 20.2 \\
\hline Min case & 60 & 1.7 & 0.23 & 0.16 & 0.02 & 0.60 & 30.8 \\
\hline
\end{tabular}
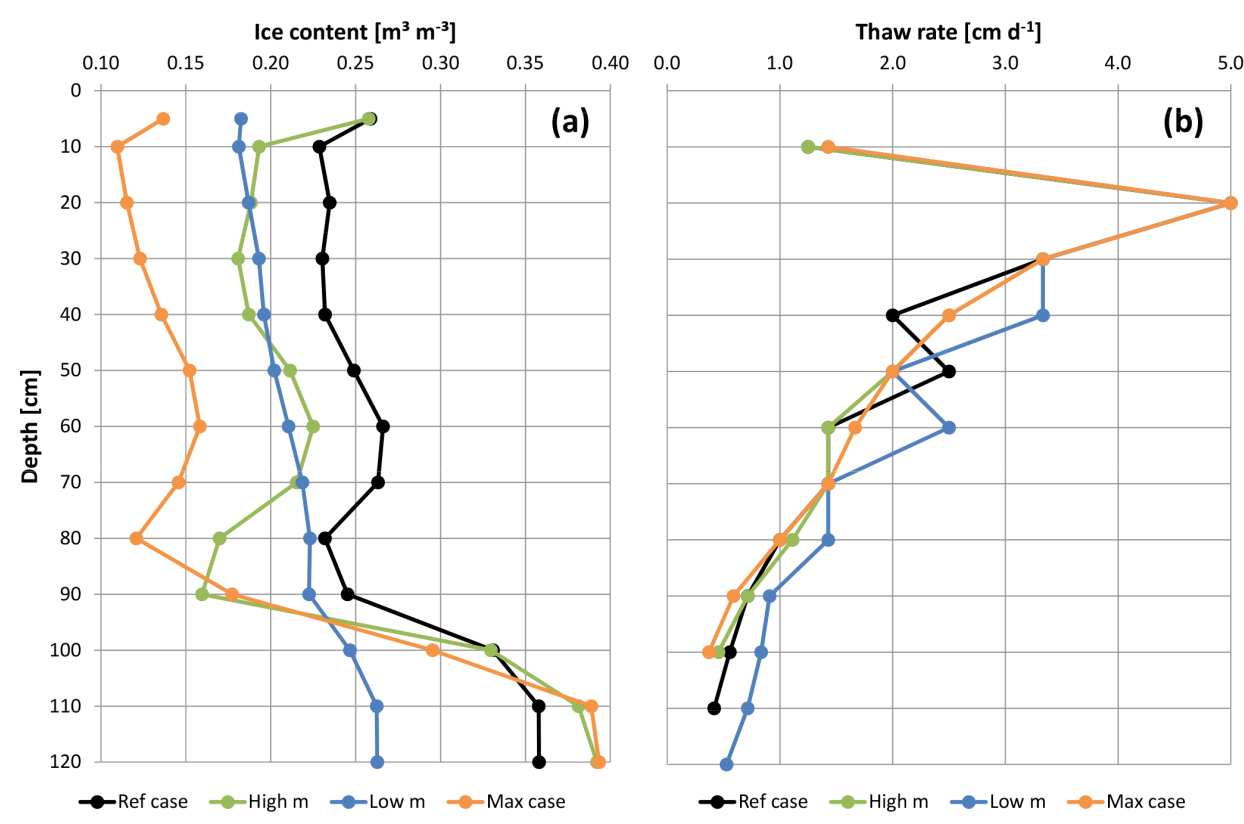

Figure 5. Comparison of (a) simulated ice content distribution with depth at the end of winter 2011 (1 May 2011) and (b) the corresponding modelled rate of active layer thaw starting after the first day of positive ground surface temperatures (25 May 2011), exemplified by four selected model scenarios.

depth. Here, discrepancies originate from the particular iceliquid-gas composition in the thawing ground and its effect on heat propagation, as discussed above. Furthermore, enhanced thaw due to advective heat transport through previously frozen water is likely to occur in more saturated systems such as "ref case" (e.g. at $50 \mathrm{~cm}$ depth). Scenarios "high $m$ " and "low $m$ " show discrepancies in their thaw rate, while having comparable ice contents. In "high $m$ ", the thaw rate drops to $1.4 \mathrm{~cm} \mathrm{~d}^{-1}$ when reaching the clearly defined icerich zone at $60 \mathrm{~cm}$ depth, whereas the thaw rate at that depth is much higher $\left(2.5 \mathrm{~cm} \mathrm{~d}^{-1}\right)$ in the "low $m$ " case, characterized by a more stable ice content profile.

\subsection{Inter-annual active layer variation and permafrost development}

Despite the differences in heat propagation through the subsurface and the resulting greater ALTs in scenarios using low $m$ values, the inter-annual variation in ALT over the study period follows a consistent pattern irrespective of soil water retention properties. The large inter-annual air temperature variations in Svalbard are mainly due to the extreme maritime location with particularly high temperature fluctuations during the long Arctic winter (Humlum et al., 2003). Accordingly, the winter WDD index (see Sect. 3.1) shows a high variability over the study period and ranges between -40 and -54 (with coefficient of variation $\mathrm{CV}=0.09$ ), compared to relatively stable summer conditions where SDD ranges between 26 and 31 only $(\mathrm{CV}=0.04)$ (Figs. 6a-b and 7), consistent with similar calculations reported by Christiansen et 
al. (2013). The field measurements of thaw depth show comparatively small inter-annual variations, except for the years 2005 and 2008 where probing of the CALM grid identified exceptionally small and large thaw depths of $74 \mathrm{~cm}$ and $110 \mathrm{~cm}$, respectively (Fig. 6a-b and Table 5, grid average). Recall also that the ground surface temperature measurements indicate essentially constant or slightly cooling summer temperatures with a trend of $-0.05^{\circ} \mathrm{C} \mathrm{yr}^{-1}$, but with a notable winter warming trend of $+0.25^{\circ} \mathrm{Cyr}^{-1}$ over the time period 2000-2014.

Note that the smallest thaw depth during the study period, measured in 2005, occurred after three consecutive and comparatively cold winters 2002-2004 (Fig. 6). The deepest thaw depth, measured in 2008, occurred after two moderate and warm winters 2006 and 2007. Although the active layer (by definition) responds to the current year's summer warming, such decreased versus increased temperature changes from previous years will affect the subsurface thermal state by depth lags in heat propagation and energy storage. Note also that although the SDD index in 2005 is rather low, consistent with the shallow active layer occurring that year, it is also low in 2008, which is inconsistent with the deep active layer occurring in 2008. This, combined with the previously mentioned observation that the SDDs vary much less than the WDDs, supports the proposition that WDDs and hence winter temperature and duration are the more dominant factors controlling active layer thickness at the UNISCALM site on Svalbard.

A mechanistic explanation for this is that active layer thickness will in general not respond symmetrically to colder versus warmer surface conditions. Colder summers can directly cause a decrease in ALT by not providing sufficient heat for a typical thaw depth, as seen in 2005, whereas an increase in ALT by warmer summers can be impeded by ice-rich conditions at the permafrost table causing a latent heat buffer. Thus, a relatively moderate increase in summer thermal conditions as observed by the SDD index may not necessarily provide sufficient heat to thaw fully or near-fully ice saturated permafrost. Such a buffering function of an icerich upper permafrost conforms to the concept of a transition zone (Shur et al., 2005). Accordingly, latent heat buffer effects may counterbalance thaw in warmer years, so that the transition zone increases overall thermal stability in the underlying permafrost. Only after a sufficient number of consecutive warm winters or years would such a transition zone eventually degrade enabling the active layer to deepen.

In contrast to the field observations, the simulated ALTs showed a more pronounced correlation to SDD (with $\left.R^{2}=0.41-0.87\right)$ and a comparatively weak correlation to WDD (with $R^{2}=0.12-0.19$ ) (Fig. 5c-d for four selected scenarios). The predominant effect of summer conditions is reflected in the shallow ALTs that have been simulated for the years 2005 and 2008 (Table 5). Both these years were characterized by cold summers with SDD $=26$ and 27, and preceded by average winters with $\mathrm{WDD}=-47$ and -45 , respectively. The large thaw depth in 2008 is, however, not captured by the models. Assuming that the thaw depth occurring in 2008 is caused by heat storage in the permafrost, this could indicate that thermal storage effects are not correctly captured by the current setups. The missing sensitivity of soil water retention parameters to inter-annual ALT variation is consistent with previous studies (Harp et al., 2016). This might be explained by the fact that in areas subject to a seasonal freeze/thaw cycle, the water retention parameters mainly control the seasonal soil moisture (re-)distribution during freezing and thaw (see Sect. 5.1). While we found the different retention curves to affect the rate of thaw progression and thus the respective annual thaw depth, the total period of active layer development from thaw to freeze-back was similar in all cases (see Sect. 5.2). In this setting, water retention characteristics therefore seem to be relevant mainly on a short time scale during thaw and freeze-up. Model results by Atchley et al. (2016) support this assumption and suggest that soil water content alone may only have a minor impact on long-term active layer development since the amount of water in the subsurface balances the competing effects of thermal conduction and latent heat.

Several studies have identified significant correlation between summer degree days and active layer depths (e.g. Christiansen, 2004; Smith et al., 2009). However, Osterkamp (2007) found warming winters to be a main cause for increasing permafrost temperatures in the Arctic Coastal Plain, Alaska, while summers even showed a slight cooling. The importance of winter conditions for thaw during the subsequent summer has also been emphasized by Burn and Zhang (2010). For their study site in the Mackenzie Delta, Canada, they found that observed variation in ALT could only partially be explained by the varying summer temperatures, and they showed that ALT was also influenced by preceding winter conditions because of a change of energy components entering the ground. After warmer winters less energy was required to warm the subsurface (sensible heat), so that more energy could be used to thaw the ground (latent heat). Wintertime snow cover thickness and duration has been shown to exhibit control on the ground thermal regime (Lafrenière et al., 2013). Also, Mackay and Burn (2002) investigated 20 years of active layer development after the artificial drainage of Lake Illisarvik in Arctic Canada, where they identified the warming of the subsurface following increases in snow depths as the major controlling factor for the observed variation in ALT as opposed to summer weather conditions.

The limited effectiveness of increased summer temperatures for increasing ALT identified here for the UNISCALM site calls for a more cautious consideration of thermal influencing factors. In the Arctic, the future temperature rise is expected to be most pronounced during winter and precipitation is expected to increase (IPCC, 2013) especially as snow during autumn and winter (Kattsov et al., 2005). Increased snow thickness and/or duration should affect the ground thermal 

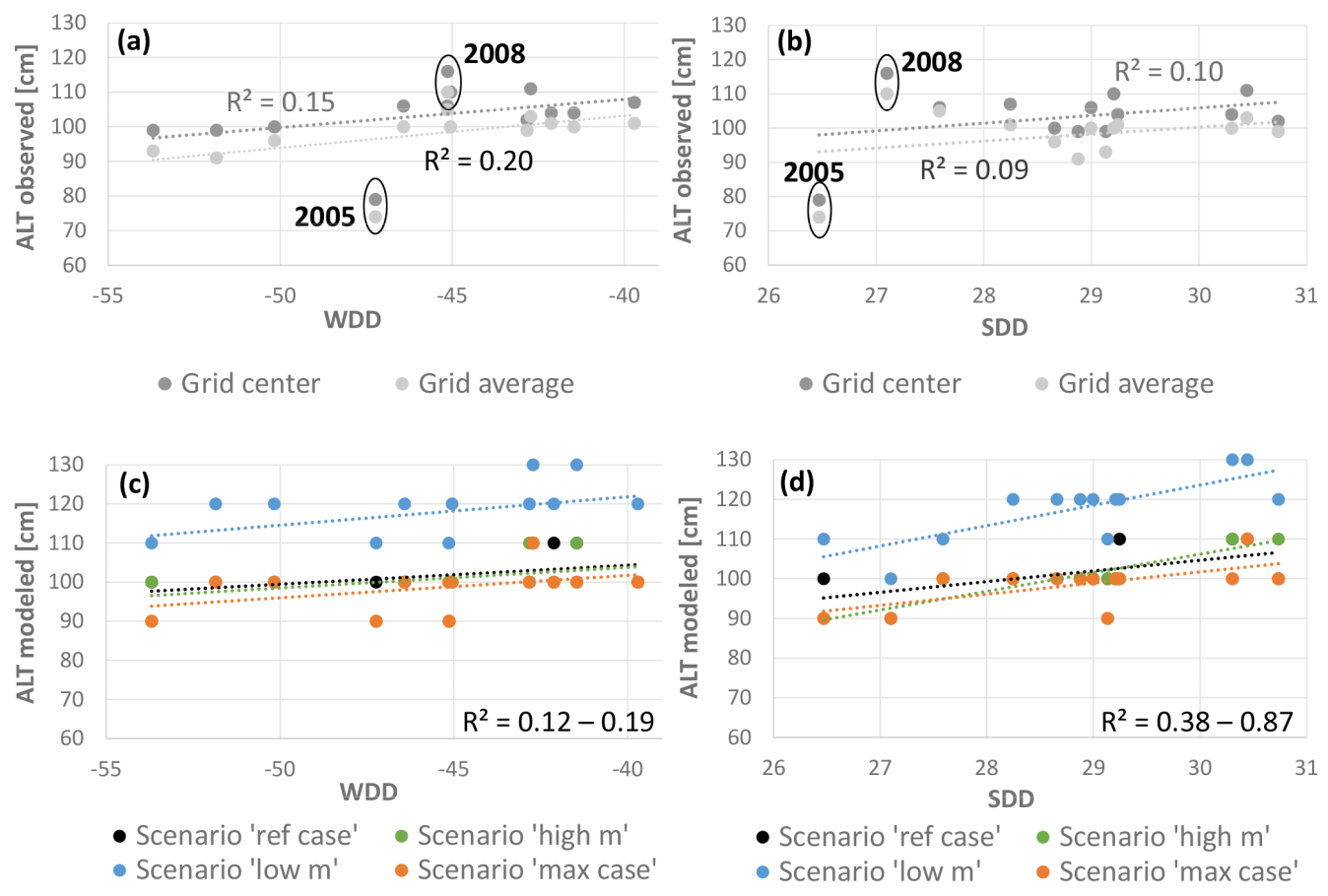

Figure 6. $(\mathbf{a}, \mathbf{b})$ Correlation of observed and $(\mathbf{c}, \mathbf{d})$ modelled active layer thicknesses to thermal conditions at the ground surface, considering winter degree days (WDD) and summer degree days (SDD) separately. Observed active layer measurements include information both from the grid centre (dark grey) and the grid average (light grey). Modelled active layer thickness is shown for selected scenarios "ref case" (black), "low $m$ " (blue), "high $m$ " (green), and "max case" only (orange).

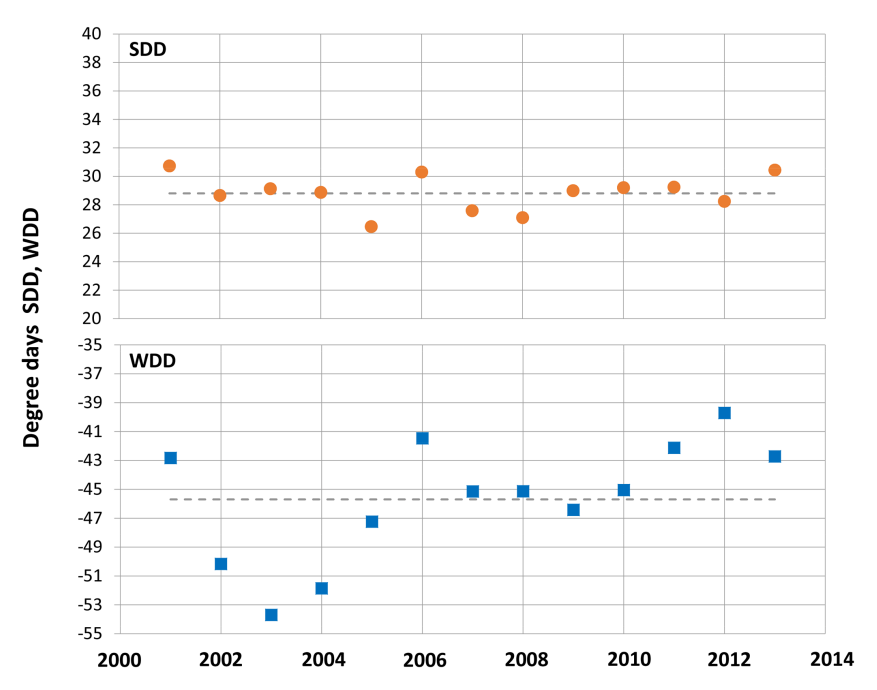

Figure 7. Summer degree days (SDD, circles) and winter degree days (WDD, squares) as an indicator for the thermal conditions at the ground surface over the course of the study period. The dashed lines indicate the respective means over the time period.

regime such that progressive active layer deepening and permafrost warming may be expected even if summer temperatures remain stable or decrease. At the same time, the effect of active layer deepening may lag behind surficial warming by several years if an ice-rich transition zone near the permafrost table exists.

\section{Summary}

The active layer dynamics at a dry loess-covered terrace site in central Svalbard was studied based on a high-resolution field data set combining active layer and permafrost temperatures, soil moisture, and active layer thaw depth progression in conjunction with a physically based coupled permafrosthydrogeological model. Simulations were configured based on site conditions and then used to investigate how different soil moisture retention curves consistent with the silt loam sediment texture observed at the site impacted active layer thickness, heat propagation, and subsurface temperatures, as well as moisture and ice redistribution by wetting and cryosuction. The main conclusions related to the stated investigation questions are as follows.

Even when constrained to a single sediment type (silt loam), the specific choice of retention parameter values leads to different moisture and ground ice distributions. In particular, well-sorted textures with small pore size variability (large exponent $m$ in the van Genuchten retention curve) lead to more distinct subsurface ice redistribution and stratification. 
The seasonal temperature variability during freeze-up exerts significant control on cryosuction leading to inter-annual differences in subsurface ice redistribution.

The choice of retention parameter values also impacts thermal properties through phase partitioning, as well as the amount of unfrozen water content at temperatures below freezing, resulting in different latent heat consumption and heat propagation rates in both the active layer and top permafrost.

The simulations showed that the highest thaw rates occur for textures which result in medium-to-high effective thermal conductivity and medium-to-low latent heat consumption, corresponding to poorly sorted textures with large pore size variability (small exponent $m$ ). These high thaw rates also led to both larger active layer thickness and stronger inter-annual variations in active layer thickness.

Water retention characteristics control the local progression of the thawing front due to the unique ice-liquid-gas composition in the subsurface, the existence of ice layers with varying ice content, and possible advective heat transport in more saturated systems.

Active layer thickness, as observed in the field, responded primarily to the cumulative temperature during the preceding winters, as opposed to cumulative summer temperatures during thaw.

Deepening of the active layer at this site is mainly controlled by consecutive years of winter warming; an immediate response is impeded by a latent heat buffer caused by ice-rich conditions near and below the permafrost table.

Data availability. Underlying research data is publicly accessible as cited in the reference list:

The NORPERM ground temperature data:

Juliussen et al. (2010)

Eklima meteorological data:

Norwegian Meteorological Institute (2014)

\section{The Supplement related to this article is available online at doi:10.5194/tc-11-635-2017-supplement.}

Competing interests. The authors declare that they have no conflict of interest.

Acknowledgements. This study was funded by the Swedish Geological Survey SGU (project 362-1593/2013). Partial support from Stiftelsen Lars Hiertas Minne is also gratefully acknowledged. We would like to thank Ethan Coon at Los Alamos National Laboratory, NM, USA, for valuable assistance in using the ATS code, and Georgia Destouni at Stockholm University for providing scientific feedback. Furthermore, we thank numerous field assistants for their efforts in collecting measurements at the UNISCALM site. We also thank two anonymous reviewers for providing helpful comments which improved the initial version of this study.
Edited by: J. Boike

Reviewed by: two anonymous referees

\section{References}

Akerman, H. J.: Relations between slow slope processes and active-layer thickness 1972-2002, Kapp Linné, Svalbard, Nor. Geogr. Tidsskr.-Nor. J. Geogr., 59, 116-128, doi:10.1080/00291950510038386, 2005.

Andersland, O. B. and Ladanyi, B.: An Introduction to Frozen Ground Engineering, Springer US, Boston, MA, 1994.

Atchley, A. L., Painter, S. L., Harp, D. R., Coon, E. T., Wilson, C. J., Liljedahl, A. K., and Romanovsky, V. E.: Using field observations to inform thermal hydrology models of permafrost dynamics with ATS (v0.83), Geosci. Model Dev., 8, 2701-2722, doi:10.5194/gmd-8-2701-2015, 2015.

Atchley, A. L., Coon, E. T., Painter, S. L., Harp, D. R., and Wilson, C.: Influences and interactions of inundation, peat, and snow on active layer thickness, Geophys. Res. Lett., 43, 5116-5123, doi:10.1002/2016GL068550, 2016.

Bense, V., Ferguson, G., and Kooi, H.: Evolution of shallow groundwater flow systems in areas of degrading permafrost, Geophys. Res. Lett., 36, L22401, doi:10.1029/2009GL039225, 2009.

Boike, J., Roth, K., and Overduin, P. P.: Thermal and hydrologic dynamics of the active layer at a continuous permafrost site (Taymyr Peninsula, Siberia), Water Resour. Res., 34, 355-363, doi:10.1029/97WR03498, 1998.

Bryant, I. D.: Loess deposits in lower Adventdalen, Spitsbergen, Polar Res., 1982, 93-103, 1982.

Burn, C. R. and Zhang, Y.: Sensitivity of active-layer development to winter conditions north of treeline, Mackenzie delta area, western Arctic coast, in: The 63rd Canadian Geotechnical Conference, presented at the GEO2010, Calgary, Alberta, 14581465, 2010.

Cheng, G.: The mechanism of repeated-segregation for the formation of thick layered ground ice, Cold Reg. Sci. Technol., 8, 5766, doi:10.1016/0165-232X(83)90017-4, 1983.

Christiansen, H. and Humlum, O.: Interannual variations in active layer thickness in Svalbard. Presented at the Proceedings Ninth International Conference on Permafrost, June 2008, 257-262, 2008.

Christiansen, H. H.: Meteorological control on interannual spatial and temporal variations in snow cover and ground thawing in two northeast Greenlandic Circumpolar-Active-LayerMonitoring(CALM) sites, Permafrost Periglac., 15, 155-169, doi:10.1002/ppp.489, 2004.

Christiansen, H. H., Humlum, O., and Eckerstorfer, M.: Central Svalbard 2000-2011 Meteorological Dynamics and Periglacial Landscape Response, Arct. Antarct. Alp. Res., 45, 6-18, doi:10.1657/1938-4246-45.16, 2013.

Coon, E. T., David Moulton, J., and Painter, S. L.: Managing complexity in simulations of land surface and nearsurface processes, Environ. Modell. Softw., 78, 134-149, doi:10.1016/j.envsoft.2015.12.017, 2016.

Destouni, G.: Applicability of the Steady State Flow Assumption for Solute Advection in Field Soils, Water Resour. Res., 27, 2129-2140, doi:10.1029/91WR01115, 1991. 
Fitts, C. R.: Groundwater Science, Academic Press, Boston, 2nd Edn., 2013.

Frampton, A. and Destouni, G.: Impact of degrading permafrost on subsurface solute transport pathways and travel times, Water Resour. Res., 51, 7680-7701, doi:10.1002/2014WR016689, 2015.

Frampton, A., Painter, S., Lyon, S. W., and Destouni, G.: Non-isothermal, three-phase simulations of near-surface flows in a model permafrost system under seasonal variability and climate change, J. Hydrol., 403, 352-359, doi:10.1016/j.jhydrol.2011.04.010, 2011.

Frampton, A., Painter, S. L., and Destouni, G.: Permafrost degradation and subsurface-flow changes caused by surface warming trends, Hydrogeology of Cold Regions, 21, 271-280, doi:10.1007/s10040-012-0938-z, 2013.

Frauenfeld, O. W.: Interdecadal changes in seasonal freeze and thaw depths in Russia, J. Geophys. Res., 109, D05101, doi:10.1029/2003JD004245, 2004.

Freeze, R. A. and Cherry, J. A.: Groundwater, Prentice Hall, Englewood Cliffs, 1979.

French, H. M.: The periglacial environment, 3rd Edn., John Wiley and Sons, Chichester, England, Hoboken, NJ, 2007.

GCOS: Status of the Global Observing System for Climate (No. GCOS-195), World Meteorological Organization, Geneva, Switzerland, 2015.

Ghanbarian-Alavijrh, B., Liaghat, A., Huang, G.-H., and van Genuchten, M. T.: Estimation of the van Genuchten Soil Water Retention Properties from Soil Textural Data, Pedosphere, 20, 456-465, doi:10.1016/S1002-0160(10)60035-5, 2010.

Giesler, R., Lyon, S. W., Mörth, C.-M., Karlsson, J., Karlsson, E. M., Jantze, E. J., Destouni, G., and Humborg, C.: Catchmentscale dissolved carbon concentrations and export estimates across six subarctic streams in northern Sweden, Biogeosciences, 11, 525-537, doi:10.5194/bg-11-525-2014, 2014.

Gilbert, G. L.: Sedimentology and geocryology of an Arctic fjord head delta (Adventdalen, Svalbard), Master Thesis, University of Oslo, Oslo, 2014.

Harp, D. R., Atchley, A. L., Painter, S. L., Coon, E. T., Wilson, C. J., Romanovsky, V. E., and Rowland, J. C.: Effect of soil property uncertainties on permafrost thaw projections: a calibration-constrained analysis, The Cryosphere, 10, 341-358, doi:10.5194/tc-10-341-2016, 2016.

Helbig, M., Boike, J., Langer, M., Schreiber, P., Runkle, B. R. K., and Kutzbach, L.: Spatial and seasonal variability of polygonal tundra water balance: Lena River Delta, northern Siberia (Russia), Hydrogeol. J., 21, 133-147, doi:10.1007/s10040-012-09334, 2013.

Hinzman, L. D., Goering, D. J., and Kane, D. L.: A distributed thermal model for calculating soil temperature profiles and depth of thaw in permafrost regions, J. Geophys. Res.-Atmos., 103, 28975-28991, doi:10.1029/98JD01731, 1998.

Humlum, O.: Holocene permafrost aggradation in Svalbard, Geol. Soc. Spec. Publ., 242, 119-129, doi:10.1144/GSL.SP.2005.242.01.11, 2005.

Humlum, O., Instanes, A., and Sollid, J. L.: Permafrost in Svalbard: a review of research history, climatic background and engineering challenges, Polar Res., 22, 191-215, doi:10.1111/j.17518369.2003.tb00107.x, 2003.

Humlum, O., Solheim, J.-E., and Stordahl, K.: Identifying natural contributions to late Holocene climate change, Global Planet.
Change, 79, 145-156, doi:10.1016/j.gloplacha.2011.09.005, 2011.

IPCC: Climate Change: The Physical Science Basis. Contribution of Working Group I to the Fifth Assessment Report of the Intergovernmental Panel on Climate Change, edited by: Stocker, T. F., Qin, D., Plattner, G.-K., Tignor, M., Allen, S. K., Boschung, J., Nauels, A., Xia, Y., Bex, V., and Midgley, P. M., Cambridge University Press, Cambridge, United Kingdom and New York, NY, USA, 2013.

Isaksen, K., Sollid, J. L., Holmlund, P., and Harris, C.: Recent warming of mountain permafrost in Svalbard and Scandinavia, J. Geophys. Res., 112, F02S04, doi:10.1029/2006JF000522, 2007.

Jantze, E. J., Lyon, S. W., and Destouni, G.: Subsurface release and transport of dissolved carbon in a discontinuous permafrost region, Hydrol. Earth Syst. Sci., 17, 3827-3839, doi:10.5194/hess17-3827-2013, 2013.

Juliussen, H., Christiansen, H. H., Strand, G. S., Iversen, S., Midttømme, K., and Rønning, J. S.: NORPERM, the Norwegian Permafrost Database - a TSP NORWAY IPY legacy, Earth Syst. Sci. Data, 2, 235-246, doi:10.5194/essd-2-235-2010, 2010.

Kane, D. L., Hinzman, L. D., and Zarling, J. P.: Thermal response of the active layer to climatic warming in a permafrost environment, Cold Reg. Sci. Technol., 19, 111-122, doi:10.1016/0165232X(91)90002-X, 1991.

Karlsson, J. M., Lyon, S. W., and Destouni, G.: Thermokarst lake, hydrological flow and water balance indicators of permafrost change in Western Siberia, J. Hydrol., 464-465, 459466, doi:10.1016/j.jhydrol.2012.07.037, 2012.

Karra, S., Painter, S. L., and Lichtner, P. C.: Three-phase numerical model for subsurface hydrology in permafrost-affected regions (PFLOTRAN-ICE v1.0), The Cryosphere, 8, 1935-1950, doi:10.5194/tc-8-1935-2014, 2014

Kattsov, V. M., Källén, E., Cattle, H. P., Christensen, J., Drange, H., Hanssen-Bauer, I., Jóhannesen, T., Karol, I., Räisänen, J., Svensson, G., and Vavulin, S.: Future climate change: modeling and scenarios for the Arctic, in: Arctic Climate Impact Assessment Scientific Report, chapt. 4,Cambridge University Press, 2005.

Killingtveit, A., Pettersson, L.-E., and Sand, K.: Water balance investigations in Svalbard, Polar Res., 22, 161-174, doi:10.1111/j.1751-8369.2003.tb00105.x, 2003.

Koven, C., Friedlingstein, P., Ciais, P., Khvorostyanov, D., Krinner, G., and Tarnocai, C.: On the formation of high-latitude soil carbon stocks: Effects of cryoturbation and insulation by organic matter in a land surface model, Geophys. Res. Lett., 36, L21501, doi:10.1029/2009GL040150, 2009.

Kurylyk, B. L., Hayashi, M., Quinton, W. L., McKenzie, J. M., and Voss, C. I.: Influence of vertical and lateral heat transfer on permafrost thaw, peatland landscape transition, and groundwater flow, Water Resour. Res., 52, 1286-1305, doi:10.1002/2015WR018057, 2016.

Lafrenière, M. J., Laurin, E., and Lamoureux, S. F.: The Impact of Snow Accumulation on the Active Layer Thermal Regime in High Arctic Soils, Vadose Zone J., 12, doi:10.2136/vzj2012.0058, 2013.

Lyon, S. W., Destouni, G., Giesler, R., Humborg, C., Mörth, M., Seibert, J., Karlsson, J., and Troch, P. A.: Estimation of permafrost thawing rates in a sub-arctic catchment using recession flow analysis, Hydrol. Earth Syst. Sci., 13, 595-604, doi:10.5194/hess-13-595-2009, 2009. 
Mackay, J. R.: The World of Underground Ice, Ann. Assoc. Am. Geogr., 62, 1-22, doi:10.1111/j.1467-8306.1972.tb00839.x, 1972.

Mackay, J. R. and Burn, C. R.: The first 20 years (1978-1979 to 1998-1999) of active-layer development, Illisarvik experimental drained lake site, western Arctic coast, Canada, Can. J. Earth Sci., 39, 1657-1674, doi:10.1139/e02-068, 2002.

McKenzie, J. M. and Voss, C. I.: Permafrost thaw in a nested groundwater-flow system, Hydrogeol. J., 21, 299-316, doi:10.1007/s10040-012-0942-3, 2013.

McKenzie, J. M., Voss, C. I., and Siegel, D. I.: Groundwater flow with energy transport and water-ice phase change: Numerical simulations, benchmarks, and application to freezing in peat bogs, Adv. Water Resour., 30, 966-983, doi:10.1016/j.advwatres.2006.08.008, 2007.

Mualem, Y.: A new model for predicting the hydraulic conductivity of unsaturated porous media, Water Resour. Res., 12, 513-522, doi:10.1029/WR012i003p00513, 1976.

Norwegian Meteorological Institute: eKlima - online access to weather and climate data, available at: http://eklima.met.no, last access: 10 October 2014.

Ochsner, T. E., Horton, R., and Ren, T.: A New Perspective on Soil Thermal Properties Journal Paper No. J-19021 of the Iowa Agriculture and Home Economics Experiment Station, Ames, IA, Project No. 3287, supported by the Hatch Act and the State of Iowa, Soil Sci. Soc. Am. J., 65, 1641-1647, doi:10.2136/sssaj2001.1641, 2001.

Osterkamp, T. E.: Characteristics of the recent warming of permafrost in Alaska, J. Geophys. Res., 112, F02S02, doi:10.1029/2006JF000578, 2007.

Painter, S. L.: Three-phase numerical model of water migration in partially frozen geological media: model formulation, validation, and applications, Comput. Geosci., 15, 69-85, doi:10.1007/s10596-010-9197-z, 2011.

Painter, S. L. and Karra, S.: Constitutive Model for Unfrozen Water Content in Subfreezing Unsaturated Soils, Vadose Zone J., 13, doi:10.2136/vzj2013.04.0071, 2014.

Painter, S. L., Coon, E. T., Atchley, A. L., Berndt, M., Garimella, R., Moulton, J. D., Svyatskiy, D., and Wilson, C. J.: Integrated surface/subsurface permafrost thermal hydrology: Model formulation and proof-of-concept simulations, Water Resour. Res., 6062-6077, doi:10.1002/2015WR018427, 2016.

Riseborough, D., Shiklomanov, N., Etzelmüller, B., Gruber, S., and Marchenko, S.: Recent advances in permafrost modelling, Permafrost Periglac., 19, 137-156, doi:10.1002/ppp.615, 2008.

Roth, K. and Boike, J.: Quantifying the thermal dynamics of a permafrost site near Ny-Ålesund, Svalbard, Water Resour. Res., 37, 2901-2914, doi:10.1029/2000WR000163, 2001.

Scheidegger, J. M. and Bense, V. F.: Impacts of glacially recharged groundwater flow systems on talik evolution, J. Geophys. Res.Earth, 758-778, doi:10.1002/2013JF002894, 2014.

Schuh, C.: Influence of soil moisture content and infiltration on ground temperature and active layer depth in a river terrace in Adventdalen, Svalbard, Master Thesis, Stockholm University, Stockholm, Sweden, 2015.

Schuur, E. A. G., McGuire, A. D., Schädel, C., Grosse, G., Harden, J. W., Hayes, D. J., Hugelius, G., Koven, C. D., Kuhry, P., Lawrence, D. M., Natali, S. M., Olefeldt, D., Romanovsky, V. E., Schaefer, K., Turetsky, M. R., Treat, C. C., and Vonk, J. E.: Cli- mate change and the permafrost carbon feedback, Nature, 520, 171-179, doi:10.1038/nature14338, 2015.

Schwartz, F. and Zhang, H.: Fundamentals of Ground Water, Wiley, New York, 2003.

Shiklomanov, N. I. and Nelson, F. E.: Analytic representation of the active layer thickness field, Kuparuk River Basin, Alaska, Ecol. Model., 123, 105-125, 1999.

Shur, Y., Hinkel, K. M., and Nelson, F. E.: The transient layer: implications for geocryology and climate-change science, Permafrost Periglac., 16, 5-17, doi:10.1002/ppp.518, 2005.

Sjöberg, Y., Coon, E., Sannel, A. B. K., Pannetier, R., Harp, D., Frampton, A., Painter, S. L., and Lyon, S. W.: Thermal effects of groundwater flow through subarctic fens-A case study based on field observations and numerical modeling, Water Resour. Res., 52, 1591-1606, doi:10.1002/2015WR017571, 2016.

Smith, S. L. and Riseborough, D. W.: Modelling the thermal response of permafrost terrain to right-of-way disturbance and climate warming, Cold Reg. Sci. Technol., 60, 92-103, doi:10.1016/j.coldregions.2009.08.009, 2010.

Smith, S. L., Wolfe, S. A., Riseborough, D. W., and Nixon, F. M.: Active-layer characteristics and summer climatic indices, Mackenzie Valley, Northwest Territories, Canada, Permafrost Periglac., 20, 201-220, doi:10.1002/ppp.651, 2009.

Tarnocai, C., Canadell, J. G., Schuur, E. A. G., Kuhry, P., Mazhitova, G., and Zimov, S.: Soil organic carbon pools in the northern circumpolar permafrost region, Global Biogeochem. Cy., 23, GB2023, doi:10.1029/2008GB003327, 2009.

Terink, W., Hurkmans, R. T. W. L., Torfs, P. J. J. F., and Uijlenhoet, R.: Evaluation of a bias correction method applied to downscaled precipitation and temperature reanalysis data for the Rhine basin, Hydrol. Earth Syst. Sci., 14, 687-703, doi:10.5194/hess-14-6872010, 2010.

van Genuchten, M. T.: A Closed-form Equation for Predicting the Hydraulic Conductivity of Unsaturated Soils, Soil Sci. Soc. Am. J., 44, 892-898, 1980.

Walvoord, M. A. and Kurylyk, B. L.: Hydrologic Impacts of Thawing Permafrost - A Review, Vadose Zone J., 15, doi:10.2136/vzj2016.01.0010, 2016.

Walvoord, M. A. and Striegl, R. G.: Increased groundwater to stream discharge from permafrost thawing in the Yukon River basin: Potential impacts on lateral export of carbon and nitrogen, Geophys. Res. Lett., 34, L12402, doi:10.1029/2007GL030216, 2007.

Walvoord, M. A., Voss, C. I., and Wellman, T. P.: Influence of permafrost distribution on groundwater flow in the context of climate-driven permafrost thaw: Example from Yukon Flats Basin, Alaska, United States, Water Resour. Res., 48, W07524, doi:10.1029/2011WR011595, 2012.

Wang, Y., Shao, M.'an, Han, X., and Liu, Z.: Spatial Variability of Soil Parameters of the van Genuchten Model at a Regional Scale: Spatial Variability of Soil Parameters of the van Genuchten Model, CLEAN - Soil Air Water, 43, 271-278, doi:10.1002/clen.201300903, 2015.

Watanabe, K. and Wake, T.: Measurement of unfrozen water content and relative permittivity of frozen unsaturated soil using NMR and TDR, Cold Reg. Sci. Technol., 59, 34-41, doi:10.1016/j.coldregions.2009.05.011, 2009.

Watanabe, T., Matsuoka, N., and Christiansen, H. H.: Mudboil and ice-wedge dynamics investigated by electrical resistivity tomog- 
raphy, ground temperatures and surface movements in Svalbard, Geografiska Annaler: Series A, Physical Geography, 94, 445457, 2012

Weismüller, J., Wollschläger, U., Boike, J., Pan, X., Yu, Q., and Roth, K.: Modeling the thermal dynamics of the active layer at two contrasting permafrost sites on Svalbard and on the Tibetan Plateau, The Cryosphere, 5, 741-757, doi:10.5194/tc-5741-2011, 2011.

Westermann, S., Wollschläger, U., and Boike, J.: Monitoring of active layer dynamics at a permafrost site on Svalbard using multichannel ground-penetrating radar, The Cryosphere, 4, 475-487, doi:10.5194/tc-4-475-2010, 2010.
Woo, M.: Permafrost Hydrology, Springer Berlin Heidelberg, Berlin, Heidelberg, 2012.

Wu, M., Tan, X., Huang, J., Wu, J., and Jansson, P.-E.: Solute and water effects on soil freezing characteristics based on laboratory experiments. Cold Reg. Sci. Technol., 115, 22-29, doi:10.1016/j.coldregions.2015.03.007, 2015.

Zhang, Y., Carey, S. K., and Quinton, W. L.: Evaluation of the algorithms and parameterizations for ground thawing and freezing simulation in permafrost regions, J. Geophys. Res., 113, D17116, doi:10.1029/2007JD009343, 2008. 